Texas A\&M University- San Antonio Digital Commons@ Texas A\&M University-San Antonio

History Faculty Publications

College of Arts and Sciences

2003

\title{
What Is Evolution? A Response to Bamforth
}

Michael J. O'Brien

Texas Aø'M University-San Antonio, Mike.Obrien@tamusa.edu

R. L. Lyman

R. D. Leonard

Follow this and additional works at: https://digitalcommons.tamusa.edu/hist_faculty

Part of the Anthropology Commons

\section{Repository Citation}

O'Brien, Michael J.; Lyman, R. L.; and Leonard, R. D., "What Is Evolution? A Response to Bamforth" (2003). History Faculty Publications. 25.

https://digitalcommons.tamusa.edu/hist_faculty/25

This Article is brought to you for free and open access by the College of Arts and Sciences at Digital Commons @ Texas A\&M University- San Antonio. It has been accepted for inclusion in History Faculty Publications by an authorized administrator of Digital Commons @ Texas A\&M University- San Antonio. For more information, please contact deirdre.mcdonald@tamusa.edu. 


\title{
COMMENTS
}

\section{WHAT IS EVOLUTION? A RESPONSE TO BAMFORTH}

\author{
Michael J. O'Brien, R. Lee Lyman, and Robert D. Leonard
}

\begin{abstract}
Douglas Bamforth's recent paper in American Antiquity, "Evidence and Metaphor in Evolutionary Archaeology," charges that Darwinism has little to offer archaeology except in a metaphorical sense. Specifically, Bamforth claims that arguments that allegedly link evolutionary processes to the archaeological record are unsustainable. Given Bamforth's narrow view of evolution-that it must be defined strictly in terms of changes in gene frequency-he is correct. But no biologist or paleontologist would agree with Bamforth's claim that evolution is a process that must be viewed fundamentally at the microlevel. Evolutionary archaeology has argued that materials in the archaeological record are phenotypic in the same way that hard parts of organisms are. Thus changes in the frequencies of archaeological variants can be used to monitor the effects of selection and drift on the makers and users of those materials. Bamforth views this extension of the human phenotype as metaphorical because to him artifacts are not somatic features, meaning their production and use are not entirely controlled by genetic transmission. He misses the critical point that in terms of evolution, culture is as significant a transmission system as genes are. There is nothing metaphorical about viewing cultural transmission from a Darwinian point of view.
\end{abstract}

El reciente trabajo de Douglas Bamforth que apareció en American Antiquity y llamado "Evidencia y metáfora en Arqueología Evolutiva" acusa al darvinismo de tener poco que ofrecer a la arqueología excepto en un amplio sentido metafórico. Específicamente, Bamforth afirma que los argumentos que supuestamente conectan la selección y el desplazamiento con el registro arqueológico son insostenibles. Dada la opinión estrecha de la evolución-que deber ser estrictamente definida en términos de cambios en frecuencia de genes-tiene razón. Pero ningún biólogo o paleontólogo estaría de acuerdo con la acusación de Bamforth de que la evolución es un proceso que deber ser considerado fundamentalmente al nivel micro. La arqueología evolutiva ha sostenido que los materiales en el registro arqueológico son fenotipos de la misma manera que lo son las partes duras de los organismos. De esta manera, los cambios en las frecuencias de las variantes arqueológicas pueden ser usados para seguir de cerca los efectos de la selección y el desplazamiento en los fabricantes y usuarios de esos materiales. Bamforth considera esta extensión de los fenotipos humanos como metafórica porque en su opinión los artefactos no son características somáticas, lo que quiere decir que su producción y uso no están controlados completamente por transmisión genética. Él no capta el punto crítico que en términos de evolución, la cultura es un sistema de transmisión tan significante como los genes. No hay nada metafórico en considerar la transmisión cultural desde un punto de vista darviniano.

$\mathrm{W}$ e appreciate constructive criticisms of evolutionary archaeology (EA hereafter) (e.g., Boone and Smith 1998; Preucel 1999; Schiffer 1996; Shennan 2002; Weiss and Hayashida 2002) because they cause us both to clarify certain points we have made and to reconsider other points in a new light. In responding to these criticisms, we have been able not only to concentrate on highlighting epistemological differences between EA and, say, human behavioral ecology (Lyman and O'Brien 1998) and behavioral archaeology (O'Brien et al. 1998) but also to point out significant areas of agreement among the various approaches (O'Brien and Lyman 2000a, 2002a). By doing so we hope to set the stage for an evolutionary synthesis in archaeology similar to that which occurred in biology and paleontology in the late 1930s and early 1940s, referred to as the New Synthesis (Huxley 1942).

The most recent criticism of EA is by Douglas Bamforth (2002), who maintains that the use of evolutionary theory and principles in archaeology is strictly metaphorical. According to Bamforth (2002:435), any arguments that link selection, or for that matter any other evolutionary process, to archaeological data are "unsustainable." Other

Michael J. O'Brien • Department of Anthropology, University of Missouri, Columbia, MO 65211

R. Lee Lyman = Department of Anthropology, University of Missouri, Columbia, MO 65211

Robert D. Leonard घ Department of Anthropology, University of New Mexico, Albuquerque, NM 87131

American Antiquity, 68(3), 2003, pp. 573-580

Copyright $\odot 2003$ by the Society for American Archaeology 
archaeologists have flatly rejected EA, but Bamforth is one of the few to offer a detailed explanation for so doing. His considerable efforts notwithstanding, Bamforth's argument is flawed and unconvincing. Bamforth not only mischaracterizes Darwinism but draws what at best can be labeled a caricature of EA, which we suspect is attributable to his making only a cursory examination of the now-extensive literature on the subject. Bamforth is selective in his citations and leaves out, for example, the booklength treatment of EA by O'Brien and Lyman (2000b) that became available a year and half before his revised manuscript was accepted. Had Bamforth read that book, or any of a number of articles written in the mid-to-late 1990s, many of the issues he raises, especially those having to do with parallels between EA and paleontology, would have been addressed. Would they have been addressed to his satisfaction? Probably not. We suspect that even had he read those works, Bamforth would not have altered his opinion or his article. He still would have claimed that EA — and he fingers human behavioral ecology as well-uses evolutionary theory metaphorically to study the past.

Why can Bamforth make such a claim? First, like other anthropologists before him, and despite all evidence to the contrary, Bamforth builds an inaccurate distinction between humanity and the rest of the natural world. Like it or not, culture and its material consequences are the result of biological phenomena. Following this, Bamforth asserts that archaeologists using evolutionary theory do not make any useful connections between evolutionary process and the material record. This argument can be made only under his narrow, reductionist definition of evolution. Bamforth adopts a familiar argumentative gambit: Structure the premise in such a way that the conclusion has to be true. And in Bamforth's case it works, but only rhetorically. If we were to view evolution solely in his terms, then we would agree with him that EA would not even be possible, let alone have any merit as a scientific approach to studying the past. But we do not agree with his limited definition of evolution, nor do biologists or paleontologists. We focus much of our attention here on the issue of what evolution entails because Bamforth's entire case rests on how one defines the term-as does the case of anyone involved in historical science. This is anything but a semantic issue.

\section{Evolution Is More Than Genes}

Bamforth (2002:436) assumes as his starting point "the universally understood meaning of 'evolution' [which] refers most fundamentally to changes through time in the relative frequency of genes in a given biological population." He does this "not because [evolution] cannot mean something more general but because using this narrow definition helps to identify important limits on archaeology's access to evolutionary process" (Bamforth 2002:436). No one seriously doubts the role played by genes in evolution, but it is only $a$ role. The important point is, evolution means significantly more than simply changes in allelic frequencies, and it is in that expanded arena that archaeology, biology, and paleontology fit comfortably. As has been pointed out numerous times, Darwin had no accurate hypothesis of biological heritability, although he knew that it was critically important to evolution. His theory of descent with modification can be written simply, without reference to genes, by using the more general term replicators - an entity that passes on its structure during reproduction (Godfrey-Smith 2000; Hull 1988). Replicators have the ability to increase in frequency exponentially, but there is a limited supply of resources they can use to do so. Thus, replicators compete for those materials, and those that are better competitors are more successful at replicating themselves. This notion of replicators is as important to EA as it is to biology and paleontology-a point that we and others have made repeatedly (Leonard and Jones 1987; Lyman and O'Brien 1998; Neff 2000, 2001; O'Brien and Lyman 2000a, 2002a).

The notion of competition between replicators and their resulting differential reproduction defines evolution via natural selection, but it leaves out drift and other sorting processes (Vrba and Gould 1986) that influence the differential reproduction of replicators. These processes became part of evolutionary theory only in the days of the New Synthesis-a period in which Darwin's mechanism of natural selection and the ideas of geneticists were wed to form the modern version of evolutionary theory. Did biologists immediately adopt a definition of evolution as genetic change? No. Ernst Mayr, a chief architect of the Synthesis, noted that to him and other naturalists in the 1940s, "evolution was not a change in gene frequencies but the 
twin processes of adaptive change and the origin of [taxonomic] diversity" (Mayr 1991:147). Given our reading of Mayr's (1942) first major book on evolution, his retrospective statement is accurate.

What about later definitions-those made well after the unification of the naturalists and the geneticists? John Endler's (1986:5) definition is typical: Evolution is "any net directional change or any cumulative change in the characteristics of organisms or populations over many generations-in other words, descent with modification. It explicitly includes the origin as well as the spread of alleles, variants, trait values, or character states." Endler (1986:14) also states that evolution "is more than merely a change in trait distributions or allele frequencies." In other words, contrary to Bamforth's alleged universally understood, "fundamental" definition, (1) phenotypic traits and characters rather than just genes can change both their states and their frequencies of expression; (2) they can change within a population as a result of vertical transmission, or what Darwin termed descent with modification; and (3) they can also change between populations as a result of horizontal transmission, or what Endler refers to as "spread." Finally, in one of the leading textbooks in evolutionary biology, evolution is defined without reference to genes. Mark Ridley (1993:5) states that "Evolution means change, change in the form and behavior of organisms between generations," and in the glossary to that book Ridley (1993:634) defines evolution as "the change in a lineage of populations between generations." These changes, spread over geological time, are what paleontologists study.

In short, there is no evidence to support Bamforth's "universally understood" definition of evolution. In paleontology, a discipline that Bamforth holds up as model of how evolutionary theory can be applied to the study of the past in nonmetaphorical terms, George Gaylord Simpson (1949a:205-206) noted shortly after the Synthesis that evolution "may be considered as change in genetic composition of populations, as morphologic change in ancestral-descendent lines, or as taxonomic progression and diversification within a line or complex of larger taxonomic scope. There are thus genetic, morphologic, and taxonomic rates of evolution." A few years earlier in his book Tempo and Mode in Evolution, which formed part of the framework for the Synthesis, Simpson (1944:xxix) attempted to wed knowledge of genetics with paleontology but admitted that "One cannot identify any particular set of alleles in fossils, but one can recognize phenomena that are comparable with those caused by alleles under experimental conditions." That is, paleontologists must assume that the phenotypic changes they perceive among a sequence of fossils comprising a lineage represent genetic change. This fact is still admitted by paleontologists (e.g., Eldredge 1989, 1999), and it always will be. Even biologists who call on the fossil record as evidence of evolution admit this. For example, biologist John Moore (2002:90) recently observed, "evolution is a historical science, which means that very little can be verified by direct observation." The fossil record particularly does "not actually show the process of change of one species into another-it could not, since fossils are not living and so do not mutate, reproduce, and undergo selection" (Moore 2002:82). And yet mutation, reproduction, and selection are precisely what Bamforth alleges that paleontologists study directly.

Because paleontologists cannot directly perceive either genes or changes in frequencies of alleles over time, they spent considerable time worrying about how to adapt the biological-species concept that emerged from the Synthesis (e.g., Arkell and Moy-Thomas 1940; Imbrie 1957; Sylvester-Bradley 1956). Ultimately, they acknowledged that fossil "species" were units bounded by morphometric criteria rather than by genetic or behavioral (reproductive behavior, particularly) ones (Newell 1949; Simpson 1940). As a result, fossil taxa were typically defined on the basis of multiple specimens (Newell 1956). These assumptions and procedures have carried over to modern paleontology (e.g., Raup and Stanley 1978). As paleontologist Richard Fox (1986:73) put it, labeling one set of fossils species A and another set species B comprises an "interpretation given to fossil evidence by the mind, within the theoretical framework of a species concept." That theoretical framework, irrespective of the chosen species concept, is Darwinism.

In his efforts to discredit EA, Bamforth ignores these points. Instead, he attempts to show that whereas EA uses evolutionary metaphor, paleontology's "success in studying evolution is undoubted" (Bamforth 2002:440). He points out that "archaeologists cannot directly observe the 
actual processes of evolution that operated in the past; instead, we are forced to infer the operation of these (and other) processes from patterns in material culture" (p. 440). We agree. If Bamforth were familiar with the paleontological literature, he would recognize that he is making the same points that paleontologists have been making for decades about the fossil record. He continues, "Furthermore, archaeological data pertain in virtually every case to the activities of groups of human beings whose social and/or familial relations are unknown, and this is especially true for analyses that aggregate data from sites scattered over large regions and long spans of time" (p. 440). Again, we agree. But notice that if we substituted "paleontological data" for "archaeological data" in the above quote and struck the word "human," all paleontologists would agree. And yet they do not characterize what they do as metaphorical, nor should they.

Despite what he sees as parallels between archaeology and paleontology, to Bamforth those similarities are "superficial and profoundly misleading. The primary data that paleontologists study are observations of the skeletal remains of past organisms. ... The problem of linking temporal patterns of change in paleontological data to evolution essentially does not arise because the link is so obvious and relatively well-understood" (Bamforth 2002:440). Here the link to which Bamforth is referring is that between genes and phenotype. Bamforth (2002:445) defines phenotype as "the outcome of an interaction between the information included in an organism's genes and the environment that organism occupies." We agree. He also notes that EA has expanded this term to include artifacts as part of the "extended phenotype," but he views this extension as metaphorical. There is nothing metaphorical about it. As EA has pointed out time and again (Dunnell 1989; Leonard 2001; Leonard and Jones 1987; O'Brien and Holland 1995; O'Brien and Lyman 2000b), pots, projectile points, houses, and myriad other cultural features are phenotypic in the same way that animal "artifacts" are. Being as tied to genes as Bamforth is, he should understand that many cultural featuresweapons and clothing to name a few-function in the same manner as a chitinous shell does: to ensure the survival of germ-line replicators (Dawkins 1982). Instead, he misses the point, claiming that EA "metaphorically equates the information required to produce an artifact with genetic information" (Bamforth 2002:445). This is incorrect. What EA has done is to view genes and culture as transmission systems that act to create variation. Whether or not that variation comes under selective control, or whether it drifts along in a population, is another matter. Important to our point here is that no evolutionary archaeologist we know of has ever equated cultural information with genetic information. Even more importantly, there is nothing metaphorical about viewing cultural transmission from a Darwinian point of view (Boyd and Richerson 1985; Durham 1991). That statement should be obvious (Bettinger and Eerkens 1999:239):

It seems clear to us that cultural transmission must affect Darwinian fitness-how could it be otherwise? And Darwinian fitness must also bear on cultural transmission. Again, how could that not be true? At minimum, humans must have the biological, hence, genetically transmitted, ability for the cultural transmission of behaviors that certainly affect Darwinian fitness. It is obvious, at the same time, that cultural transmission differs in fundamental ways from any form of genetic transmission.... Again, this is what we would expect. ... [A]s with sexual reproduction, the human use of cultural transmission is simply the exploiting of an evolutionary opportunity. To deny that would imply that the culturally mediated evolutionary success of anatomically modern humans is merely serendipitous happenstance.

Units of cultural transmission can be defined theoretically as "the largest units of socially transmitted information that reliably and repeatedly withstand transmission" (Pocklington and Best 1997:81). EA measures "the effect of transmission on variability, [and] culture-historical types, as conceived by archaeologists, are entirely [reasonable proxies for] the unit of cultural transmission" (Lipo and Madsen 2001:100; emphasis in original). The replicative success of these units is what evolutionary archaeologists seek to explain (Leonard 2001). Those units that are functional will be sorted by natural selection; those that are stylistic will be sorted by the vagaries of transmission. Whether the former units, as manifest in artifacts, influence the biological reproductive success of their human bearers is an empirical matter, the assessment of which requires the time depth provided by the 
archaeological record (O'Brien and Holland 1992). Sometimes they will, and sometimes they will not. And despite Bamforth's claims, EA has used a battery of methods, including frequency and occurrence seriation, clade-diversity diagrams, and cladograms, to determine this empirically (Lyman and O'Brien 2000; O'Brien and Lyman 2000b; O'Brien et al. 2001, 2002). What EA has not done is to develop a scale to measure changing gene frequencies between generations. Neither has paleontology.

\section{Darwinism and a "Largely Unchanging Species"}

Perhaps the underlying reason that Bamforth adopts the position he does-including his idiosyncratic definition of evolution and his approval of paleontology but not EA as an evolutionary science-is captured in this sentence: "Outside of research on the archaeology of human ancestors, archaeological data consist of observations made on the artifacts and features left behind by a single, largely unchanging species" (Bamforth 2002:440). Here Bamforth sounds curiously like a macroevolutionist-one whose interest is not in the day-to-day turnover of individuals within a species but in patterns and rates of change among lineages that lead to the origin and multiplication of species. We have detailed in numerous places that certain macroevolutionary concepts, such as punctuated equilibrium (O'Brien and Lyman 2000b), and macroevolutionary methods, such as cladistics and clade-diversity diagrams (Lyman and O'Brien 2000; O'Brien and Lyman 1999, 2000b, 2002a; O'Brien et al. 2001, 2002), are directly applicable to archaeology. Importantly, those methods can be used to study the remains of a single species such as Homo sapiens. The critical issue is not that one, two, or ten taxa are involved; rather, the issue is a matter of carefully choosing one's analytical units (Lyman and O'Brien 2002; O'Brien and Lyman 2002b). EA will often be forced to study only macroevolutionary change because the analogue of microevolutionary change among organisms is genetic, something no paleontologist has ever claimed to be able to monitor directly. Archaeologists are in the same situation; they study change in artifacts, not change in the ideas behind the artifacts (Lyman and O'Brien 2001).

As we have noted elsewhere (O'Brien and
Lyman 2000c), most archaeologists have little problem with the fact that some 5-6 million years ago the line that produced chimpanzees diverged from the line that produced hominids and eventually members of the genus Homo. When we see fossils lined up in a certain way, and we can see the profound changes that hominids have gone through during the last 5-6 million years, we ask ourselves, what else but evolution could have caused such large-scale change? Bamforth would agree. But what about change over the last 100,000 years? Can we see enough morphological change over that span to indicate evolution has taken place? Sometimes we can, or at least our taxonomic efforts suggest we can, although it is more difficult to see the cumulative changes in phenotypes separated by 100,000 years than it is in phenotypes separated by $5-6$ million years. Why? Because various evolutionary processes have had 50-60 times longer to effect change in the latter sample than in the former. This means that the effects are much more evident than they are when a shorter period of time is involved. Suppose we shorten the period to 10,000 years. Do we see any large-scale change? Not very often. Does this mean that evolution has stopped operating on humans? No, it means simply that in the vast majority of cases the time span is too short even to begin to see the large-scale changes that we customarily associate with evolution. Bamforth wants to see these large-scale changes so that he can feel assured that evolution has taken place. To him, anything less than that is not evolution, or at least it is not worth studying. He would profit from reading Jonathan Weiner's (1994) The Beak of the Finch or Peter Grant's (1999) Ecology and Evolution of Darwin's Finches. Both books make it plain that once in a while evolution can be seen empirically in successive generations of organisms, and we do not need to reach the molecular level to see it.

Archaeologists are not alone in failing to recognize the complementarity of micro- and macroevolutionary perspectives when it comes to human evolution. Several prominent evolutionary biologists and paleontologists (e.g., Gould 1996; Huxley 1956; Simpson 1949b) have also stated that humans are a "single, largely unchanging species." Under this view, evolutionary processes such as selection and drift do not operate on humans because our capacity for culture has decoupled us from evolution. If such is the case, and culture and 
its attendant features have created a gulf between humans and evolutionary processes, then a Darwinian perspective is nonapplicable to the vast majority of the archaeological record. We contend, however, that culture is simply one adaptive response that a particular lineage of organisms evolved. As such, it does not exempt its bearers from evolutionary processes.

Invoking culture as a decoupling agent locates cause in the wrong place. Culture is a different mode of transmission than genes are (Aunger 2002), but the difference does not lead to the inescapable conclusion that humans as organisms have evolved the means to stop evolving. Do these differences indicate that selection and drift play at best minimal roles in reshuffling both somatic and nonsomatic characters? No. Humans today are no more immune to evolutionary processes than they were 30,000 years ago. We agree with what at least one evolutionary biologist said about culture: It merely altered "the components of fitness [and the] directional changes" prompted by selection. "What has happened is that the [selective] environment, the adjudicator of which genotypes are fit, has been altered" (Lerner 1959:181).

Ignoring the simple dichotomy between longterm, cumulative evolutionary results and shortterm aspects of evolution is responsible for the question that bothers Bamforth. That question is, "Where's the evolution?" Skeptics such as Bamforth are looking for the big results and missing the point that those large-scale, cumulative results are the end products of countless small-scale changes that took place over a very long time period. Paleontologists do not have access to the fine detail that archaeologists can see, but they do not doubt that their macroscale picture comprises literally millions of tiny structures and routine processes that went on day after day, century after century, millennium after millennium. They accept such detail as axiomatic, just as they accept that genetic change was behind some of the change they see. Conversely, archaeologists rarely have access to anything approaching the evolutionary big picture, but we should not get so lost in detail that we forget that it is those details that cumulatively are evolution.

\section{Conclusions}

In his penultimate section, Bamforth (2002:447) states, "like evolutionary archaeology, systems archeology was going to finally make us scientists ... and lead us toward theoretical integration with other academic disciplines." We find Bamforth's statement-indeed, this entire section of his article-irrelevant. That systems theory failed to make archaeology a science implies nothing about the success or failure of EA or of any other intellectual program that offers science as a solution to many of the problems in which archaeologists are interested. More to the point, EA is not some prescriptive exercise that, if followed, turns one instantly into a scientist. All EA does-all it can do-is offer a coherent, theoretically grounded approach to examining the archaeological record. EA rests on the premise that objects in the archaeological record, because they were parts of past phenotypes, were shaped by the same evolutionary processes as were the somatic features of their makers and users. This is a shorthand way of saying that the possessors of the objects were acted on by evolutionary processes.

Bamforth (2002:449) closes his review of EA by stating, "Rigorous technical analysis and careful consideration both of multiple lines of evidence and of multiple potential explanations for patterns in that evidence are what make us competent scientists, not our commitment to any particular theoretical perspective. Systems archaeology foundered in large part because it failed to deal with issues like these, and we are well on our way to seeing whether or not evolutionary archaeology will have the same fate." All we can ask is, where does Bamforth think scientific explanation comes from if not in large part from theory? To us, explanation is one part theory and one part empirical standard (Leonard 2001; O'Brien and Lyman 2000b). EA has been particularly clear on where the theory comes from-Darwinism as generally understood by biologists and paleontologists. It has been equally clear that the empirical standards are derived from that theory, not simply from received archaeological wisdom. The data requirements for EA are high, but they usually are in science.

In sum, we find Bamforth's presentation not only unconvincing but disappointing for reasons that go far beyond this particular discussion. As Bamforth notes, other social sciences are increasingly embracing the explanatory power of Darwinian evolutionary theory (e.g., Cziko 1995). And there are good reasons for this. Evolutionary the- 
ory, as its growth in sociology, economics, psychology, and anthropology attests, now arguably explains more human behavior than any other theoretical perspective. Yet many anthropologists choose to distance themselves from evolutionary theory for the simple reason that they deeply desire for humanity to be distinct from the biological realm, despite all evidence to the contrary. Twenty years ago this attitude might have been simply unfortunate. Now it is decidedly more problematic, as not only does evolutionary theory give us great insights into the past and present, it is also clear that many problems that confront humanity today-global warming, deterioration of the ozone layer, global reduction of biodiversity, genetic engineering, AIDS, cloning, increasing bacterial resistance to antibiotics, cultural extinction-will require knowledge of evolutionary theory to solve.

Acknowledgments. We gratefully acknowledge comments by Tim Kohler, Geoff Clark, and three anonymous reviewers on how to improve the manuscript. Maria Sol Colina translated the abstract into Spanish.

\section{References Cited}

Arkell, W. J., and J. A. Moy-Thomas

1940 Palaeontology and the Taxonomic Problem. In The New Systematics, edited by J. S. Huxley, pp. 395-410. Clarendon Press, Oxford, England.

Aunger, R.

2002 The Electric Meme: A New Theory of How We Think. Free Press, New York.

Bamforth, D. B.

2002 Evidence and Metaphor in Evolutionary Archaeology. American Antiquity 67:435-452.

Bettinger, R. L., and J. Eerkens

1999 Point Typologies, Cultural Transmission, and the Spread of Bow-and-Arrow Technology in the Prehistoric Great Basin. American Antiquity 64:231-242.

Boone, J. L., and E. A. Smith

1998 Is It Evolution Yet? A Critique of Evolutionary Archaeology. Current Anthropology 39:S141-S173.

Boyd, R., and P. J. Richerson

1985 Culture and the Evolutionary Process. University of Chicago Press, Chicago.

Cziko, G.

1995 Without Miracles: Universal Selection Theory and the Second Darwinian Revolution. MIT Press, Cambridge, Massachusetts.

Dawkins R.

1982 The Extended Phenotype. Oxford University Press, Oxford, England.

Dunnell, R. C.

1989 Aspects of the Application of Evolutionary Theory in Archaeology. In Archaeological Thought in America, edited by C. C. Lamberg-Karlovsky, pp. 35-49. Cambridge University Press, Cambridge, England.

Durham, W. H.

1991 Coevolution: Genes, Culture, and Human Diversity.
Stanford University Press, Palo Alto, California.

Eldredge, $\mathrm{N}$.

1989 Time Frames: The Evolution of Punctuated Equilibrium, rev. ed. Princeton University Press, Princeton, New Jersey.

1999 The Pattern of Evolution. Freeman, New York.

Endler, J. A.

1986 Natural Selection in the Wild. Monographs in Population Biology 21. Princeton University Press, Princeton, New Jersey.

Fox, R. C.

1986 Species in Paleontology. Geoscience Canada 13:73-84.

Godfrey-Smith, $P$.

2000 The Replicator in Retrospect. Biology and Philosophy 15:403-423.

Gould, S. J.

1996 Full House: The Spread of Excellence from Plato to Darwin. Harmony, New York.

Grant, P. R.

1999 Ecology and Evolution of Darwin's Finches. Princeton University Press, Princeton, New Jersey.

Hull, D.

1988 Interactors versus Vehicles. In The Role of Behavior in Evolution, edited by H. C. Plotkin, pp. 19-50. MIT Press, Cambridge, Massachusetts.

Huxley, J. S.

1942 Evolution, the Modern Synthesis. Allen and Unwin, London.

1956 Evolution, Cultural and Biological. In Current Anthropology, edited by W. L. Thomas, Jr., pp. 3-25. University of Chicago Press, Chicago.

Imbrie, J.

1957 The Species Problem with Fossil Animals. In The Species Problem, edited by E. Mayr, pp. 125-153. American Association for the Advancement of Science, Publication No. 50. Washington, D.C.

Leonard, R. D.

2001 Evolutionary Archaeology. In Archaeological Theory Today, edited by I. Hodder, pp. 65-97. Polity Press, Cambridge, England.

Leonard, R. D., and G. T. Jones

1987 Elements of an Inclusive Evolutionary Model for Archaeology. Journal of Anthropological Archaeology 6:199-219.

Lerner, I. M.

1959 The Concept of Natural Selection: A Centennial View. Proceedings of the American Philosophical Society 103:173-182.

Lipo, C. P., and M. E. Madsen

2001 Neutrality, "Style," and Drift: Building Models for Studying Cultural Transmission in the Archaeological Record. In Style and Function: Conceptual Issues in Evolutionary Archaeology, edited by T. D. Hurt and G. F. M. Rakita, pp. 91-118. Bergin and Garvey, Westport, Connecticut.

Lyman, R. L., and M. J. O'Brien

1998 The Goals of Evolutionary Archaeology: History and Explanation. Current Anthropology 39:615-652.

2000 Measuring and Explaining Change in Artifact Variation with Clade-Diversity Diagrams. Journal of Anthropological Archaeology 19:39-74.

2001 On Misconceptions of Evolutionary Archaeology: Confusing Macroevolution and Microevolution. Current Anthropology 42:408-409.

2002 Classification. In Darwin and Archaeology: A Handbook of Key Concepts, edited by J. P. Hart and J. E. Ter- 
rell, pp. 69-88. Bergin and Garvey, Westport, Connecticut.

Mayr, E.

1942 Systematics and the Origins of Species. Columbia University Press, New York.

1991 One Long Argument: Charles Darwin and the Genesis of Modern Evolutionary Thought. Harvard University Press, Cambridge, Massachusetts.

Moore, J. A.

2002 From Genesis to Genetics: The Case of Evolution and Creationism. University of California Press, Berkeley.

Neff, $\mathrm{H}$.

2000 On Evolutionary Ecology and Evolutionary Archaeology: Some Common Ground? Current Anthropology 41:427-429.

2001 Differential Persistence of What? The Scale of Selection Issue in Evolutionary Archaeology. In Style and Function: Conceptual Issues in Evolutionary Archaeology, edited by T. D. Hurt and G. F. M. Rakita, pp. 25-40. Bergin and Garvey, Westport, Connecticut.

Newell, N. D.

1949 Types and Hypodigms. American Journal of Science 247:134-142.

1956 Fossil Populations. In The Species Concept in Palaeontology, edited by P. C. Sylvester-Bradley, pp. 63-82. The Systematics Association, London.

O'Brien, M. J., J. Darwent, and R. L. Lyman

2001 Cladistics Is Useful for Reconstructing Archaeological Phylogenies: Paleoindian Points from the Southeastern United States. Journal of Archaeological Science 28:1115-1136.

O'Brien, M. J., and T. D. Holland

1992 The Role of Adaptation in Archaeological Explanation. American Antiquity 57:36-59.

1995 Behavioral Archaeology and the Extended Phenotype. In Expanding Archaeology, edited by J. M. Skibo, W. H. Walker, and A. E. Nielsen, pp. 143-161. University of Utah Press, Salt Lake City.

O'Brien, M. J., and R. L. Lyman

1999 Meeting Theoretical and Methodological Challenges to the Future of Evolutionary Archaeology. Review of Archaeology 20:14-22.

2000a Evolutionary Archaeology: Reconstructing and Explaining Historical Lineages. In Social Theory in Archaeology, edited by M. B. Schiffer, pp. 126-142. University of Utah Press, Salt Lake City.

2000b Applying Evolutionary Archaeology: A Systematic Approach. Kluwer Academic/Plenum Press, New York.

2000c Darwinian Evolutionism Is Applicable to Historical Archaeology. International Journal of Historical Archaeology 4:71-112.

2002a Evolutionary Archaeology: Current Status and Future Prospects. Evolutionary Anthropology 11:26-36.

$2002 \mathrm{~b}$ The Epistemological Nature of Archaeological Units. Anthropological Theory 2:37-57.
O’Brien, M. J., R. L. Lyman, Y. Saab, E. Saab, J. Darwent, and D. S. Glover

2002 Two Issues in Archaeological Phylogenetics: Taxon Construction and Outgroup Selection. Journal of Theoretical Biology 215:133-150.

O'Brien, M. J., R. L. Lyman, and R. D. Leonard

1998 Basic Incompatibilities between Evolutionary and Behavioral Archaeology. American Antiquity 63:485-498.

Pocklington, R., and M. L. Best

1997 Cultural Evolution and Units of Selection in Replicating Text. Journal of Theoretical Biology 188:79-87.

Preucel, R. W.

1999 Review of "Evolutionary Archaeology: Theory and Application" by M. J. O'Brien. Journal of Field Archaeology 26:93-99.

Raup, D. M., and S. M. Stanley

1978 Principles of Paleontology, 2nd ed. Freeman, San Francisco.

Ridley, M.

1993 Evolution, 2nd ed. Blackwell Science, Cambridge, Massachusetts.

Schiffer, M. B.

1996 Some Relationships between Behavioral and Evolutionary Archaeologies. American Antiquity 61:643-662.

Shennan, $\mathrm{S}$.

2002 Archaeology Evolving: History, Adaptation, SelfOrganization. Antiquity 76:253-256.

Simpson, G. G.

1940 Types in Modern Taxonomy. American Journal of Science 238:413-431.

1944 Tempo and Mode in Evolution. Columbia University Press, New York.

1949a Rates of Evolution in Animals. In Genetics, Paleontology and Evolution, edited by G. L. Jepsen, G. G. Simpson, and E. Mayr, pp. 205-228. Princeton University Press, Princeton, New Jersey.

1949b The Meaning of Evolution. Yale University Press, New Haven, Connecticut.

Sylvester-Bradley, P. C. (editor)

1956 The Species Concept in Palaeontology. The Systematics Association, London.

Vrba, E. S., and S. J. Gould

1986 The Hierarchical Expansion of Sorting and Selection: Sorting and Selection Cannot Be Equated. Paleobiology 12:217-228.

Weiner, J.

1994 The Beak of the Finch: A Story of Evolution in Our Time. Knopf, New York.

Weiss, K., and F. Hayashida

2002 KulturCrisis! Cultural Evolution Going Round in Circles. Evolutionary Anthropology 11:136-141.

Received September 17, 2002; Revised November 15, 2002; Accepted November 18, 2002. 